IRSTI 06.39.02

UDC 338.984

https://doi.org/10.46914/1562-2959-2020-1-4-240-244

A.K. MARALOV, ${ }^{1}$

PhD student.

L.N. Gumilyov Eurasian

National University ${ }^{1}$

\title{
ACTUALIZATION OF THE ISSUES \\ OF THE TELECOMMUNICATION SPHERE DEVELOPMENT OF THE REPUBLIC OF KAZAKHSTAN
}

\begin{abstract}
The telecommunications industry is one of the few sectors of the national economy that has managed to survive a period of general decline in the national economy and is currently an attractive niche for attracting investment. This industry is characterized as the "circulatory" system of the state. In addition, the telecommunications industry is the most important sector of the economy, ensuring the functioning and coordination of all government systems and, of course, is currently designated as dynamically developing. All this determines the interest and relevance for the author's research. The article discusses the conceptual construct of studying the real sector of the economy in the framework of management approaches. The main positions of the Strategic Plan for the Development of the Republic of Kazakhstan up to 2025 and the «Digital Kazakhstan» Program in the framework of the strategic planning of the national economy are stipulated and specified. The development of the telecommunications market, which is becoming the most important element of the economic development of the Republic of Kazakhstan and strengthening the country's authority in the international community, has been systematized. On the example of «KazTransCom» JSC, the production activity of a telecommunications enterprise is shown taking into account the use of elements of modern management, including the competency model. The author's research results are shown, the goal of which is the achievement of strategic goals by the personnel of a particular enterprise. The article discusses the issues of qualitative growth of the telecommunications system, the competitiveness of the industry. Attention is focused on modern industry trends and prospects. According to the results of the study, relevant conclusions were drawn related to the feasibility of monitoring.
\end{abstract}

Key words: strategic planning, telecommunications industry, competitiveness, enterprise, personnel, industry trends, management approaches, national economy.

In the modern world the development of any state is based on the development of a strategy.

A strategy is a general program of action that identifies problem priorities and resources to achieve the main goal. This concept in the study of management processes generates the following conceptual construct:

- strategic management is management in socio-economic systems where functional, process and elemental aspects are distinguished;

- strategic management - the process of forming a strategic vision by management, setting goals, developing and implementing strategies, timely adjusting the vision, goals, strategy and implementation;

- strategic planning is the process of creating and implementing programs and action plans, and activities related in space (by performers) and in time (in terms of time), aimed at fulfilling strategic objectives $[1,3]$.

The essence of the strategic planning of economic and political processes is determined by the strategy of the state, which refers to the direction of changing the balance of forces of social strata at a certain stage of historical development.

The main objective of the Strategic Plan 2025 is to create a sustainable model of development of the country with a high level of well-being and living standards of the population, which will be based on a wide middle class, the dominant business sector and competitive enterprises [2].

The implementation of the Nation Plan - 100 concrete steps to implement the five institutional reforms will lay the foundations for a qualitatively new and competitive institutional environment characteristic of developed countries. This will contribute to the growth of the country's competitiveness, the development of entrepreneurial initiatives and private capital, the development of civil society. 
Global trends point to the increasing importance of the service sector in economic development in both developed and developing countries. Moreover, as the welfare of the population increases, the service economy begins to play a key role in ensuring economic growth and employment.

The main priorities for the development of macroregions (West, South, North and Center-East) should be the introduction of the hub principle and the further formation on this basis of the basis for the agglomerative development of the cities of Shymkent, Aktobe and Ust-Kamenogorsk.

Managed urbanization will allow Kazakhstan to significantly increase the competitiveness of the economy through its diversification and increase in labor productivity.

Within the framework of strategic planning, the state will promote the development of entrepreneurship, especially small and medium-sized businesses, for which a more favorable business climate will be created, facilitating the creation and operation of enterprises.

In order to increase the competitiveness of human capital, the state's efforts in the area in the next decade will focus on the formation of a skilled and productive workforce that is economically and geographically mobile.

The economy of Kazakhstan until 2014 was developing dynamically. Due to the fact that the lion's share of exports of the country are metals and hydrocarbons, the fall in prices for "black gold" and minerals on the market led to a weakening of the national currency, a deficit in the republican budget and a number of other phenomena that instantly affected at the level of income of the population and the business environment.

The number of investment projects also began to decline. The telecommunications industry also did not remain without negative changes.

Currently Kazakhstan is focused on the third wave of modernization and massive development of the IT sector. However, investments in the telecommunications market are still falling. According to Finprom analysts, in 2016 the amount of injections decreased by 39\% to 63 billion tenge (\$196.9 million). At the same time, more attention is paid to the industry by foreign investors than by the state. The adoption of the "Digital Kazakhstan" program in 2017 will be able to return investors' attention to the anchor industry for the new generation of the economy - telecommunications. In 2016, the volume of investments in the fixed capital of communications enterprises amounted to only 63 billion tenge. This is $39 \%$ less than the volume of injections for 2015, and more than 2 times less than the amount of investments in 2012. The share of the telecommunications sector in the total investment in the economy in 2016 was only $0.8 \%$ [4].

In this regard, noting the lack of significant growth in the telecommunications industry, competition between large and medium-sized players in this market is increasing day by day. Potential customers are beginning to postpone the delivery of facilities, large companies are forced to reduce their local budget, investing in new projects that potential contractors have hoped for are "frozen", respectively, competition between operators is becoming tougher.

Thus, such a problem as the need to develop a new strategy for a telecommunications company is very important. Otherwise, the company's life cycle will approach its logical bankruptcy.

One of their promising enterprises is the Aktyubinsk Branch, which was established on the basis of the Aktyubinsk operational and technical communications office (later, from 1986, the West Kazakhstan Communications Department and AktyubneftSvyaz JSC), which provided services to the largest oil producing company in the region. Then, after the collapse of the USSR and through transformations, in 2001. «Aktyubneftesvyaz» OJSC was merged with «KazTransSvyaz» OJSC, thereby becoming the Aktyubinsk Branch of «KazTransCom» JSC.

«KazTransCom» JSC is a leading telecom operator providing a wide range of services in the field of telecommunications and information technologies.

The values of «KazTransCom» JSC are:

- client-centeredness;

- responsibility;

- professionalism;

- innovativeness;

- personnel.

The principle of work of «KazTransCom» JSC is that communication is not only technology and equipment, it is, first of all, personnel, cooperation, ideas, readiness to solve any tasks. 
Today, the total staff of the branch is 136 people, the average age is 42 years.

Currently, the company is developing various areas of activity, opening up opportunities for staff development in new market segments.

Moreover, «KazTransCom» JSC implements the «Model of Competences», which is a set of behavior, which is the result of the employee's knowledge, skills, abilities and personal qualities that are necessary for him to successfully complete tasks.

The competence model is a set of key competencies required by employees at all levels for successful work and achievement of the Company's strategic goals, described in a standardized form through behavioral indicators, fair policy in relation to their employees, which operates at all stages of personnel work.

It is also important that the company cares about the welfare and social security of its employees and their families, implements social programs. The Company also supports veterans, pensioners, disabled workers and families of workers who suffered in the workplace.

In this case, the number of employees with experience of more than 30 years is 33 persons $(24 \%$ of the total staff). This is mainly technical staff. With this analysis, the average work experience is 12.5 years.

In the author's research using the questionnaire method, the goal was to reveal the general opinion of the staff regarding the need to diversify the company's client portfolio and to identify the staff's attitude to change.

Respondents were offered nine closed-ended questions on a Likert type scale with five answers:

- fully agree;

- agree;

- difficult to answer;

- disagree;

- strongly disagree.

The respondent must answer the question in such a way that it is in an affirmative form.

30 employees from the technical, commercial, financial and administrative units were selected as respondents. 17 of the respondents are men, 13 respondents are women. Figure 1 shows the percentage of age and gender grades.

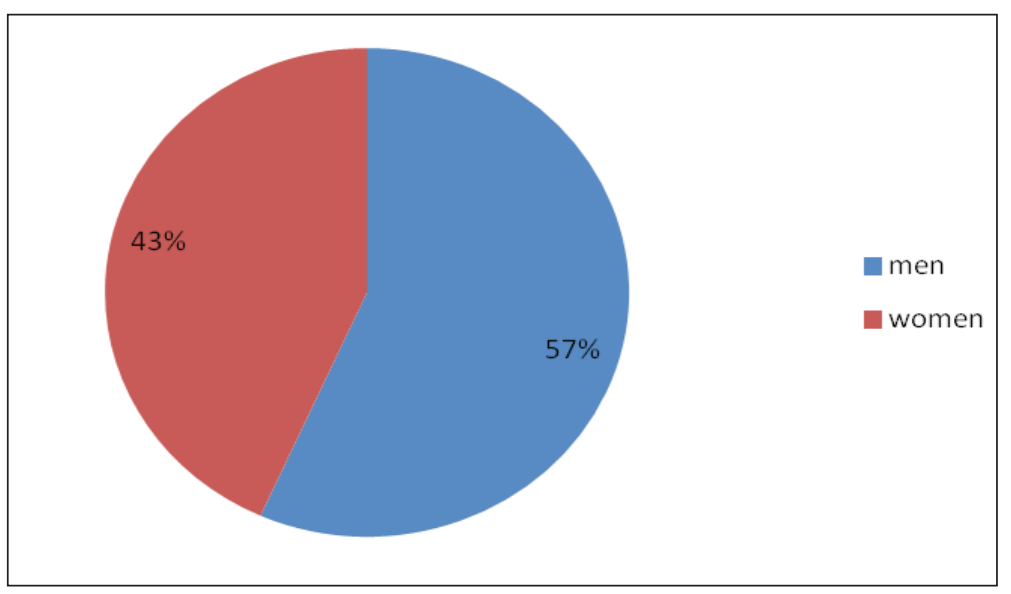

Figure 1 - Ratio of respondents, $\%$

Among the respondents surveyed were presented both representatives of the top management of companies (deputy directors, department heads) -8 respondents, middle managers -4 respondents, and ordinary workers (18 people). Questionnaires of specialists of different levels helped to get an objective opinion on these issues. It should also be noted that the respondents are representatives of a company with various lengths of service from 0.5 to 30 years.

The results showed that the company's staff, which over the past 2-3 years has been experiencing all the negative effects of the crisis, a decrease in physical volumes and branch revenue, as well as a downgrade of the company among competitors, is ready to expand the client base (medium, small 
business) and (public sector) segments. Among them was not disagreeing with the opinion of the staff. As for the (individual entrepreneurs and individuals) segment, here, about $64 \%$ of the staff more agree with the opinion that it is necessary to expand in this direction, almost $23 \%$ disagree with this opinion, $3 \%$ found it difficult to answer.

Since "KazTransCom" JSC is a telecom company with the ability to introduce new products in the field of IT technologies, the majority of employees (87\%) believe that it is necessary to introduce new products.

The results show the presence of the appropriate attitude of the staff to changes within the company, changes in the composition of the client portfolio, and also show the level of customer focus of employees.

Particular attention is paid to the quality of production processes and the performance of all IT equipment. The equipment by means of which customers have access to high quality service is produced in Israel, the USA and Europe. Specialists of the company visit international partner companies such as Cisco (USA), Gilat (Israel) and others to learn and share experiences. The knowledge gained is successfully implemented and used in the production process. One of the achievements of the companies is that the company employs three specialists who are certified by Cisco Certified Internetwork Expert Routing and Switching (CCIE R \& S). In total, only 19 such specialists work in Kazakhstan.

«KazTransCom» JSC operates on the basis of an integrated management system:

- ISO 9001:2008 - Quality Management System;

- CT RK 9001:2009 - Quality Management System;

- ISO 14001:2004 - Environmental management system;

- ISO/IEC 27001:2013 - Information security system;

- OHSAS 18001:2007 - Personnel Health and Safety Management System.

Thus, «KazTransCom» JSC creates conditions for staff development for joint success.

\title{
LIST OF LITERATURE
}

1 Alexandrova A.V. Strategic management / N.A. Kazakova, A.V. Alexandrova, S.A. Kurashova, N.N. Kondrasheva. - M.: SIC INFRA-M, 2013. -320 p.

2 Strategic Development Plan of the Republic of Kazakhstan until 2025: https://pandia.ru/text/80/239/ 9861.php.

3 Akmaeva R.I. Strategic management. - Moscow: Ruscience, 2017. - 252 p.

4 The Profit Information and Analytical Portal, the Digital Kazakhstan Project will be presented in June Access: http://profit.kz/news/36965/Proekt-gosprogrammi-Cifrovoj-Kazahstan-prezentuut-v-iune/.

А.Қ. МАРАЛОВ, ${ }^{1}$

докторант.

Л.Н. Гумилев атындағы Еуразия

ұлттық университеті ${ }^{1}$

\section{ҚАЗАҚСТАН РЕСПУБЛИКАСЫНДАҒЫ \\ ТЕЛЕКОММУНИКАЦИЯ САЛАСЫНЫН ДАМУ МӘСЕЛЕЛЕРІН ӨЗГЕРТУ}

\begin{abstract}
Андатпа
Телекоммуникация саласы - бұл ұлттық экономикадағы жалпы рецессия кезеңінен аман-есен өткен және қазіргі кезде инвестицияларды тарту үшін тартымды орынға ие болған ұлттық экономика салаларының бірі. Бұл сала мемлекеттің «қанайналым» жүйесі ретінде сипатталады. Сонымен қатар телекоммуникация саласы барлық мемлекеттік жүйелердің жұмыс істеуі мен үйлесуін қамтамасыз ететін экономиканың ең маңызды секторы болып табылады және, әрине, қазіргі уақытта қарқынды дамып келе жатқан бағыт ретінде белгіленді. Мұның бәрі авторлық зерттеу үшін қызығушылық пен өзектілікті анықтайды. Мақалада басқарудың тәсілдері шеңберінде экономиканың нақты секторын зерттеудің тұжырымдамалық аппараты талқыланады. Ұлттық экономиканы стратегиялық жоспарлау аясындағы Қазақстан Республикасының 2025
\end{abstract}


жылға дейінгі стратегиялық даму жоспарының және «Цифрлық Қазақстан» бағдарламасының негізгі ұстанымдары айқындалды және нақтыланды. Қазақстан Республикасының экономикалық дамуының маңызды элементіне айналатын және елдің халықаралық қоғамдастықтағы беделін күшейтетін телекоммуникация нарығын дамыту мәселелері жүйеленді. «KazTransCom» АҚ мысалында қазіргі заманғы басқару элементтерін, оның ішінде құзыреттілік моделін қолдануды ескере отырып, телекоммуникация кәсіпорнының өндірістік қызметі көрсетілген. Авторлық зерттеудің нәтижелері көрсетілген, оның мақсаты белгілі бір кәсіпорынның персоналымен стратегиялық мақсаттарға жету болып табылады. Мақалада телекоммуникация жүйесінің сапалық өсуі, саланың бәсекеге қабілеттілігі туралы айтылады. Назар саланың қазіргі салалық тенденциялары мен перспективаларына аударылады. Зерттеу нәтижелері бойынша бақылаудың орындылығына байланысты тиісті қорытындылар жасалды.

Тірек сөздер: стратегиялық жоспарлау, телекоммуникация саласы, бәсекеге қабілеттілік, кәсіпорын, персонал, салалық тенденциялар, басқару тәсілдері, ұлттық экономика.

\author{
А.К. МАРАЛОВ, ${ }^{1}$ \\ докторант. \\ Евразийский национальный \\ университет им. Л.Н. Гумилева ${ }^{1}$
}

\title{
АКТУАЛИЗАЦИЯ ВОПРОСОВ РАЗВИТИЯ ТЕЛЕКОММУНИКАЦИОННОЙ СФЕРЫ РЕСПУБЛИКИ КАЗАХСТАН
}

\begin{abstract}
Аннотация
Телекоммуникационная отрасль - одна из немногих отраслей национальной экономики, которая сумела пережить период общего спада в национальном хозяйстве и в настоящее время является привлекательной нишей для привлечения инвестиций. Данная отрасль характеризуется как «кровеносная» система государства. Кроме того, телекоммуникационная отрасль является важнейшим сектором экономики, обеспечивающим функционирование и согласовывание всех государственных систем, и, безусловно, в настоящее время обозначена как динамично развивающаяся. Все это обусловливает интерес и актуальность проведения авторского исследования. В статье рассмотрен понятийный аппарат изучения реального сектора экономики в рамках управленческих подходов. Обусловлены и конкретизированы основные позиции Стратегического плана развития Республики Казахстан до 2025 года и программы «Цифровой Казахстан» в рамках стратегического планирования национальной экономики. Систематизированы вопросы развития телекоммуникационного рынка, который становится важнейшим элементом экономического развития Республики Казахстан и укрепления авторитета страны в международном сообществе. На примере $\mathrm{AO}$ «KazTransCom» показана производственная деятельность предприятия телекоммуникационной сферы с учетом использования элементов современного менеджмента, в том числе модели компетенций. Показаны результаты авторского исследования, цель которых - достижение стратегических целей персоналом конкретного предприятия. В статье рассмотрены вопросы качественного роста телекоммуникационной системы, конкурентоспособности отрасли. Акцентировано внимание на современных отраслевых тенденциях и перспективах. По результатам проведенного исследования сделаны соответствующие выводы, связанные с целесообразностью проведения мониторинга.
\end{abstract}

Ключевые слова: стратегическое планирование, телекоммуникационная отрасль, конкурентоспособность, предприятие, персонал, отраслевые тенденции, управленческие подходы, национальная экономика. 